\title{
Cooperation between Weimar and Budapest on computational modelling of steel and composite structures
}

The paper overviews the long-term cooperation between the Bauhaus University, Weimar and the Budapest University of Technology and Economics on computational modelling of structures. The cooperation consists of diverse elements of research activities, experimental and numerical model-based development of design methods for innovative structural details of industrial halls, bilateral education of students at different levels (BSc, MSc and $\mathrm{PhD}$ ), cooperative supervision of $\mathrm{PhD}$ researches and review of $\mathrm{PhD}$ theses. The fruitful cooperation is closely linked to the friendly relationship between Prof. Frank Werner and Prof. László Dunai, who jointly organized and managed the main part of the common research and educational activities. The common research results significantly extended the state-of-the-art knowledge of the design of light-gauge roof systems for industrial halls, of the design of shear connectors in cold-formed composite slabs and of the modelling of cyclic plasticity. Hungarian students had the opportunity to study at the Bauhaus University, Weimar during Summer Schools organized by Prof. Werner. He also hosted two Hungarian PhD Students in Weimar, and a German PhD student had a research stay in Budapest under the guidance of Prof. Dunai. The current paper gives a summary of the most important activities and results of this two-decade long cooperation, which are all linked to the computational modelling of steel and composite structures. The paper also congratulates Prof. Frank Werner on his $70^{\text {th }}$ birthday.

Keywords computational modelling; FEM-based design; cold-formed roof system; cyclic plastic material model; composite slab

1 Introduction

The cooperation between the Bauhaus University, Weimar and the Budapest University of Technology and Economics (BME) started more than 20 years ago with an industrial research and development project on the topic of experimental and numerically based design of innova-

*) Corresponding author: dunai.laszlo@epito.bme.hu

Submitted for review: 10 January 2019

Accepted for publication: 02 February 2019
Zusammenarbeit zwischen Weimar und Budapest bei der rechnergestützten Modellierung von Stahl- und

Verbundkonstruktionen

Der Beitrag gibt einen Überblick über die langjährige Zusammenarbeit zwischen der Bauhaus-Universität Weimar und der Budapester Universität für Technik und Wirtschaft bei der rechnergestützten Modellierung von Tragwerken. Die Zusammenarbeit umfasst verschiedene Elemente der Forschungsaktivitäten, die Entwicklung experimenteller und numerischer modellbasierter Bemessungsmethoden für innovative Tragwerkdetails von Industriehallen, die bilaterale Ausbildung von Studierenden auf verschiedenen Ebenen (BSc, MSc und PhD) sowie die gemeinsame Betreuung von Doktoranden und Gutachten zu Dissertationen. Die fruchtbare Zusammenarbeit ist das Resultat der freundschaftlichen Beziehung von Prof. Frank Werner und Prof. László Dunai, die den überwiegenden Teil der gemeinsamen Forschungs- und Lehrtätigkeit organisiert und geleitet haben. Die gemeinsam erarbeiteten Forschungsergebnisse haben den Wissensstand über die Bemessung von Dachtragwerken mit dünnwandigen Profilen für Industriehallen, über die Auslegung von Schubverbindern kaltgeformten Verbundblechen und über die Modellierung zyklischer Plastizität erweitert. Studenten aus Ungarn hatten die Gelegenheit, im Rahmen von durch Prof. Werner organisierten Summer Schools an der Bauhaus-Universität Weimar zu studieren. Darüber hinaus betreute er zwei ungarische Doktoranden in Weimar, und ein deutscher Doktorand verbrachte einen Forschungsaufenthalt in Budapest unter der Leitung von Prof. Dunai. Der vorliegende Beitrag bietet zu Ehren des 70. Geburtstags von Prof. Frank Werner einen Überblick über die wichtigsten Aktivitäten und Ergebnisse dieser zwei Jahrzehnte währenden Zusammenarbeit. Sie alle befassen sich mit der rechnerischen Modellierung von Stahl- und Verbundkonstruktionen.

Keywords rechnerische Modellierung; FE-basierte Bemessung; Dachtragwerke aus kaltgeformten Stahlprofilen; zyklisch-plastisches Materialmodell; Verbunddecke

tive roof systems for industrial halls. The research was funded at first by Butler Ltd., followed by Lindab Ltd. and Astron Ltd. The basic research on this topic was started in the two universities separately, and the R\&D project combined their results, each of which were able to extend and improve the other in an effective manner. The results of this cooperative research work are still widely applied in the design of roof systems, and they serve as the basis of further product development and to establish new experimental and numerical model-based design methods. The cooperation has been continued and extended in the 
form of PhD research activities and the education of students. Prof. Dunai has been a regularly invited lecturer at the Summer Schools and PhD Seminars organized by the Bauhaus University, Weimar, and Prof. Werner has also led seminars in Budapest. Hungarian PhD students - Dr. Noémi Seres and Dr. Viktor Budaházy - had the opportunity to join the research group in Weimar for a longer period under the guidance of Prof. Werner, and a PhD student - Dr. Markus Reuter - from Weimar also spent a longer study period in Budapest; Prof. Dunai was later the reviewer of his $\mathrm{PhD}$ thesis. The cooperation in the $\mathrm{PhD}$ education programme helped each side to learn from the different research methodologies and improved the scientific assessment of the common $\mathrm{PhD}$ theses.

All the common research activities and education programmes had as their main focus the computational modelling of steel and composite structures and the experimental and numerical analysis-based development of design methods. The cooperation continued in a common $\mathrm{PhD}$ course on the numerical modelling-based design of steel structures. This is a common $\mathrm{PhD}$ course of the two universities in the context of an Erasmus+ Strategic Partnership. The current paper summarizes the main outcomes of the common research and educational activities. It introduces the experimental and numerical based analysis and design of industrial hall roof systems using thin-walled cold-formed structures, presents the results of innovative research work on the design of shear connectors of composite floors with trapezoidal sheets, presents the results of innovative research work on the development of a cyclic plastic steel material model and reports on the introduction of the FEM-based design in $\mathrm{PhD}$ education.

Experimental and numerical modelling-based design of cold-formed roof systems

Cold-formed profiles and sheeting are frequently used structural elements in the area of industrial and residential buildings. The application field of these elements is currently growing due to their numerous favourable properties. The most important advantages are the resistance to weathering conditions (weather tightness, durability), resistance to corrosion, together with reliability and recyclability. Furthermore, the cold-formed elements make possible a simple and fast building process, which results in a cost-effective building erection method. However, the cost of the secondary structural elements and the cladding system can be a significant element in the total price of an industrial building. The development of purlin-roof systems can therefore effect remarkable savings, which indicates a need for the continuous development of structural systems and design methods in practice. Experimental and numerical research work in the field of coldformed thin-walled roof systems (Fig. 1) is conducted at the BME Department of Structural Engineering in partial collaboration with the Bauhaus University, Weimar [1][5].

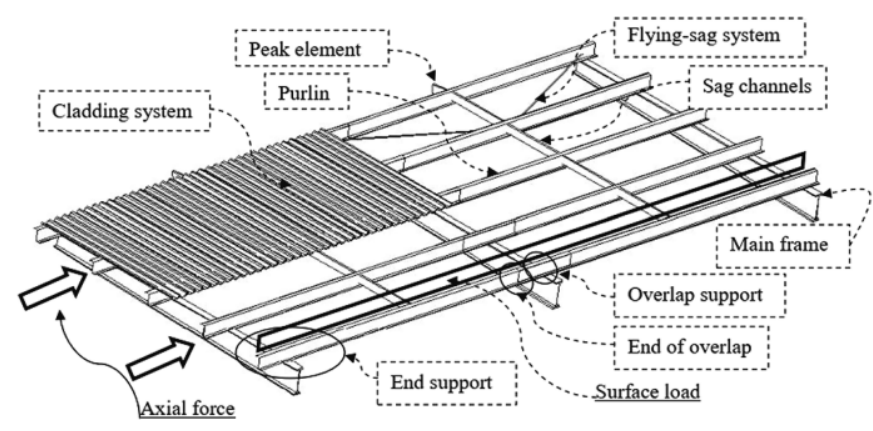

Fig. 1 Typical cold-formed thin-walled roof system: components and loads. Typisches Dachtragwerk aus kaltgeformten, dünnwandigen Profilen: Bauteile und Lasten.

As part of the research work, the roof system using coldformed profiles and sheeting has been improved to meet the requirements coming from the constructional and structural-resistance aspects. The development resulted in cold-formed cross-sections with complex geometry and complicated structural behaviour in addition to the interacting effect of the different structural elements. Due to the complex geometry, the complicated structural system, the non-conventional purlin-sheeting connections and the non-homogeneous material properties through the cross-section, the development of improved design methods was needed for the overall design. As part of the research work conducted, the roof system was investigated by experimental and numerical research tools, resulting in an advanced design method. The design process that was developed, and the improved structural solutions significantly enhanced the performance and economics of the roof systems being examined. In the experimental study, different purlin-sheeting connections are tested and analysed. Laboratory and large scale on-site tests are also carried out to study the structural behaviour of the complex static system. The research focused specially on the determination of the lateral spring stiffness of the roof systems when using different cladding systems and purlins. The main research aims were the following:

- investigation of the interaction phenomena between the purlins and sheets,

- determination of the effects of the different parameters of the lateral spring stiffness, such as: (i) depth and thickness of Z-purlins, (ii) thickness of trapezoidal sheets, (iii) numbers of fasteners, and (iv) loading directions,

- provision of a verification background for the newly developed design models.

Different types of cladding systems represent different rotational and lateral restraints to the purlin, and these differences should be considered in the design. The rotational restraining effect of the cladding system on the behaviour of Z-purlins has been analysed by analytical, experimental and numerical tools through the cooperation between Weimar and Budapest [1]-[3]. A design method was developed in Weimar [2] and a target program, called PurlinFED, was developed in BME [4], [5]. The PurlinFED program can prepare the data and com- 


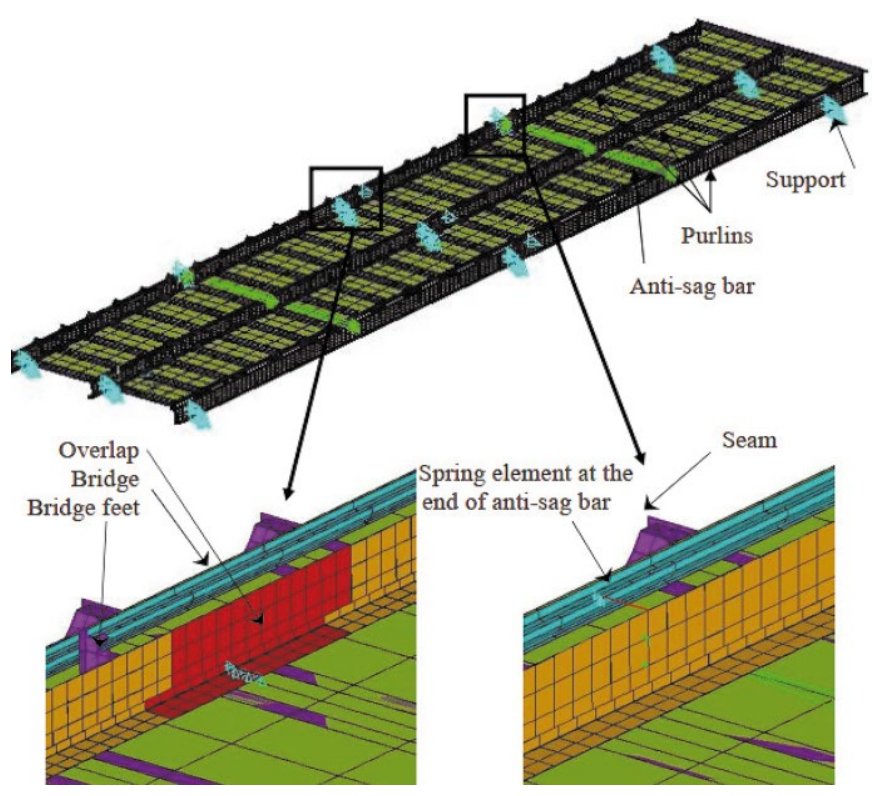

Fig. 2 Finite element model of a complex roof system used for FE-based design.

Finite-Element-Modell eines komplexen Dachtragwerkes für die FE-basierte Bemessung

plete the analysis for the design of the roof systems studied. The full model of the roof system takes into consideration the actual rotational rigidity of the cladding system, where the slenderness of the purlin can be determined by instability analysis of a shell FE model. The automatic buckling mode classifications helps in choosing the pure lateral torsional buckling mode for calculating the relevant reduction factors. The most complex design method is the nonlinear simulation of imperfect shell finite element models, which was also used in the resistance determination. While EN 1993-1-5 for plated structures gives design rules on the application of shell finite element method-based design, EN 1993-1-3, however, specifies no equivalent geometrical imperfections for cold-formed members, so experimentally verified imperfection sensitivity analysis is carried out to analyse and determine the applicable imperfection shapes and magnitudes. The model of the roof system summarizes the experiences with finite element modelling of cold-formed thin-walled members gathered during the research. Two types of roof systems are studied: (i) roof with trapezoidal sheeting and (ii) roof with floating cladding system. Fig. 2 shows the application of the shell model on a segment of a roof system that consists of three purlins, simulating the full-scale on-site experiments [1], [4].

The design method that was developed and applied joins together (i) the test-based design resistances of the components that have no standardized background and (ii) the EN 1993-1-5 based nonlinear simulation of imperfect shell finite element models [5]. The algorithm developed contains three design levels for roof systems: a) beam model extended by the experimentally determined overlap rigidity and proposed design methods for end of overlap and end support, b) beam model extended by the shell finite element-based buckling analysis, where the slender- ness ratios are determined from the full FE model of the roof system that contains the real rotational support provided by the cladding system to the purlin, and c) shell finite element model, where material and geometrical nonlinear simulations are carried out on an imperfect model. Imperfections are based on the buckling modes of the purlin, which are classified by the built-in buckling mode recognition algorithm. The proposed algorithm is verified and validated on the basis of the ultimate behaviour of the nonconventional purlin-cladding system studied by a full-scale experimental programme, using partly the methodology developed in [6]. Further details of the numerical model developed, and its application, can be found in [4] and [5].

\section{3}

\section{Modelling of shear connectors of composite slabs} with trapezoidal steel sheeting

Intensive common research work has been conducted as part of a $\mathrm{PhD}$ thesis on composite floor systems, which are widely used in industrial and high-rise buildings. The reinforced concrete floor deck is usually cast on trapezoidal corrugated steel sheeting, which provides formwork for the slab during construction, and after hardening, the profile deck and the concrete act as a composite slab. The composite floor should be designed for three typical failure modes, such as bending, vertical shear and horizontal shear, the latter being the most common one. The interface interlock is normally created mainly by rolled embossments, the resistance of which governs the horizontal shear resistance of the slab. The aim of the research work carried out is to determine the horizontal shear resistance of the rolled embossments, to understand the failure mechanism and to develop a semi-empirical calculation method for the resistance. The failure mode of an individual embossment under horizontal shear is a local phenomenon which can be governed by three different mechanisms, as shown in Fig. 3. As a first step, the three components are considered independently by assuming that the weaker part of the connection fails, while the other remains undamaged. The main focus of the common research work of Budapest and Weimar was to establish the background of the steel embossment-type failure by experimental and numerical studies.

Steel-type failure is analysed first on an individual enlarged embossment with a spherical shape subjected to a pull-out test and followed by numerical modelling. The basic model consisted of one embossment and the surrounding concrete. The experimental background is as-

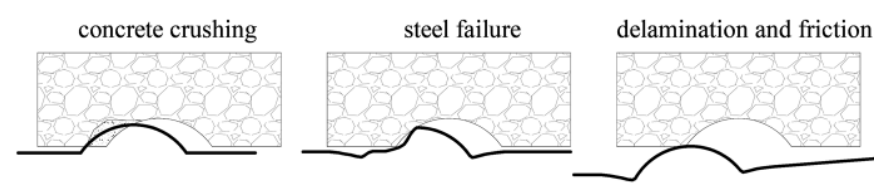

Fig. 3 Theoretical local failure modes of embossments. Theoretische lokale Versagensmodi der Vertiefungen. 

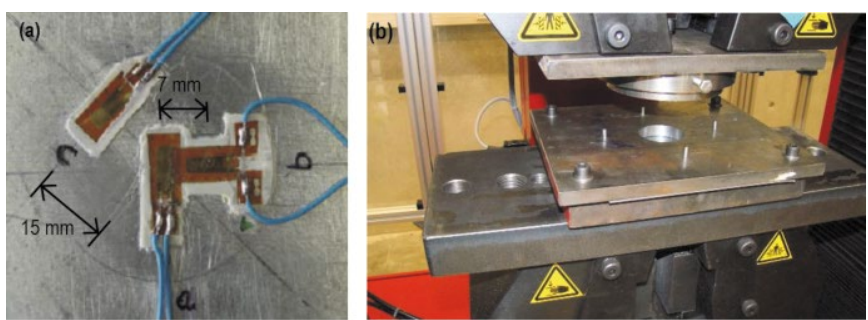

Fig. 4 Test setup for extrusion process of individual enlarged embossment. Versuchsaufbau für den Extrusionsprozess einer einzelnen, vergrößerten Vertiefung.
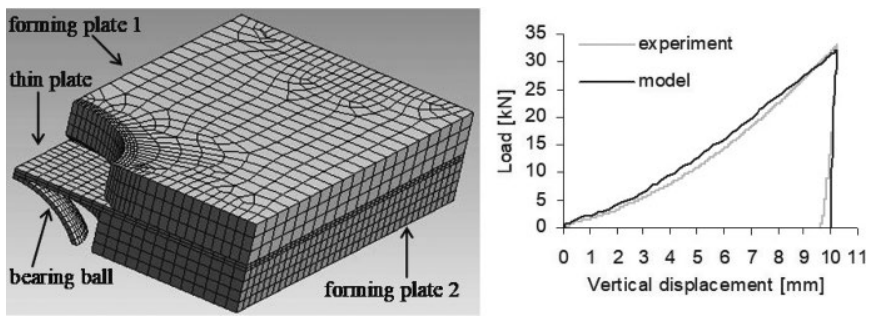

Fig. 5 Numerical model of extrusion process and the relevant loaddisplacement curves.

Numerisches Modell des Extrusionsprozesses und die entsprechenden Last-Verformungskurven.

sembled from in-house experiments as well as from experiments found in the international literature. The test procedure and the model developed are extended to analyse a series of real-size embossments in order to link the local behaviour of one embossment and the global behaviour of the interface consisting of numerous embossments. The calculation method is developed to determine the horizontal shear resistance of the steel embossment and a proposal is made for concrete-type failure as well.

Laboratory tests are therefore carried out to determine the effect of the 3D extrusion process on an embossment resistance in the CIB structural laboratory of the Bauhaus University, Weimar. The test results are mainly used for numerical model validation. Thin-walled steel plates are equipped by 3-3 strain gauges (Fig. 4) and embossments are formed on the plate under load control using an electromechanical universal static testing machine. A numerical model is developed to simulate the extrusion process and to determine the load-displacement relationship as well as the strains of the manufacturing process based on the experimental results (Fig. 5). The numerical model is built up from higher ordered solid elements by experimentally validated nonlinear material models, using verification methods detailed in [6].

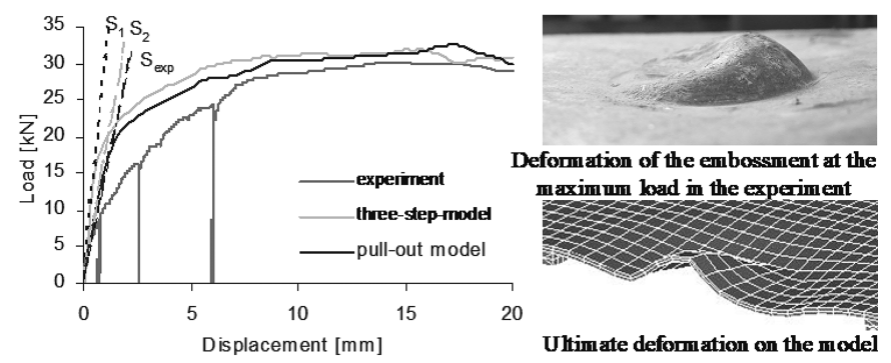

Fig. 7 Comparison of the computed and measured load-displacement diagrams and deformation shapes. Vergleich der berechneten und gemessenen Last-Verformungsdiagramme und Verformungsformen.

A three-step model is developed by incorporating the extrusion process of the embossment in the thin plate before the pull-out test is performed on it to analyse the different phases of manufacturing and loading of the steel embossment. The three modelling steps are: (i) extrusion process denoted by $\mathrm{e}_{1}$ on Fig. 6.b, (ii) removal of the bearing ball ( $\mathrm{e}_{2}$ on Fig. 6.b), and (iii) pull-out test of the embossment ( $e_{3}$ on Fig.6.b). The numerical model and the modelled load-step details are presented in Fig. 6 .

In the numerical models the sheeting is characterized by a linear elastic - hardening plastic material model, the concrete is assumed to be the non-damageable part of the model, and in the geometric nonlinear analysis large displacements as well as strains are considered [6]-[8]. Based on the comparison of the two numerical models and the test results, as presented in Fig. 7, the structural behaviour of the embossment and the effect of the manufacturing process is evaluated. From a comparison of the different models it is found that the initial stiffness of the threestep model $\left(\mathrm{S}_{2}\right)$ is smaller compared with the one-step pull-out model $\left(\mathrm{S}_{1}\right)$. However, almost the same load carrying capacity is reached by both models.

The initial stiffness has good correlation with the experimental results $\left(\mathrm{S}_{\exp }\right)$ until the first yielding occurs within the steel plate. The difference between the experimental and numerical load-displacement curves after yielding can be explained by the local concrete damage that occurred during the experiment. The connection model between the contacting surfaces is found to be essential in the modelling, which is studied in detail. By implementing the extrusion process in the numerical model, it is found that the initial stiffness of the system decreased, but it did not have a significant effect on the load-carrying capacity. The numerical model developed is proved to be appropriate for further application in complex composite slabs.
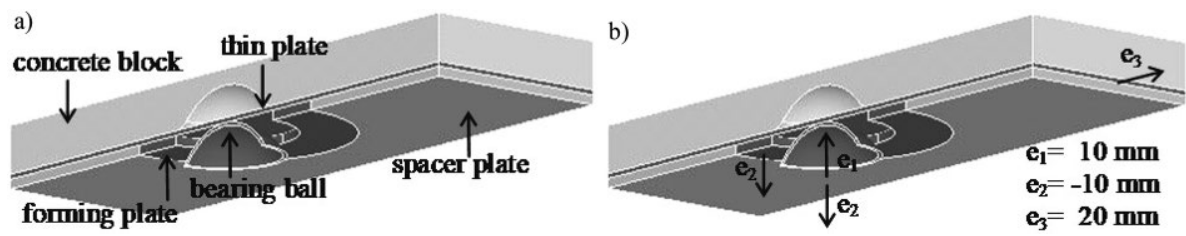

Fig. 6 Details of (a) model and (b) loading steps. Detail von (a) Modell und (b) Laststufen. 
4

\section{Development of cyclic plastic material models}

The cooperation between the two universities also involves seismic research, especially on the local and global ductility of steel structures. The cyclic plastic behaviour of steel material significantly determines the structural response during an earthquake event, therefore a comprehensive knowledge of structural-steel behaviour under large inelastic cyclic loading is important. Experimental research work has been carried out in $\mathrm{Bu}-$ dapest in the field of the cyclic plasticity of steel structures to understand and explore the most relevant elements of the structural behaviour. The experimental research programme serves as the basis of newly developed steel-material models (PRESCOM, PRESCOM Memory). The models were also implemented in an advanced finite element environment, with the aim of simulating and improving dissipative-zone models of steel structures. The cyclic steel behaviour has been investigated from the 1960s, and the major elements in steel plasticity have been investigated by several researchers (Bauschinger effect, combined hardening, low-cyclic fatigue, ratcheting effect, strain rate). However, under more complex or arbitrary load paths, such as those shown in Fig. 8 and typical during a seismic event, additional cyclic phenomena can be explored. These are the key issues of the experimental research programme, namely (i) qualitative and quantitative evaluation of memory behaviour; (ii) hardening behaviour under more complex load history, especially the effect of small loops during a load path and preloading; (iii) experiments with steel material manufactured under European specifications, and higher steel grades. The experimental programme is performed considering a total of 31 uniaxial load protocols up to $12 \%$ strain. As well as the description of the tendencies, quantified variables and empirical equations were presented for the description of the hardening and memory behaviour of steel material. It is found that hardening develops with three components: (i) isotropic hardening component, which depends on the maximum strain level $\left(\Delta \sigma_{\text {isomax }}\right)$; (ii) additional isotropic hardening component $\left(\Delta \sigma_{\text {accum }}\right)$, which depends on the accumulated plastic strain; and (iii) kinematic hardening component $\left(\Delta \sigma_{\text {kin }}\right)$, which gradually increases between 0 and $1.5-2 \%$ strain [10].
On the basis of the experimental programme, an improved Chaboche model is developed, partly during the study period of $\mathrm{V}$. Budaházy in Weimar. The model is based on the combination of nonlinear kinematic (a Chaboche model with five superposed Armstrong-Frederick formulas) and multi-linear isotropic hardening with a parameter-refreshing method. The model is called PRESCOM - Parameter REfreshed and Strain COntrolled combined Chaboche Model with isotropic hardening rule. This model can consider the different physical phenomena of steel behaviour under cyclic loading, and is appropriate for increasing loading protocols. The model called PRESCOM Memory is also developed for decreasing and arbitrary load paths, and can consider the separation of isotropic hardening components $\left(\Delta \sigma_{\text {isomax }}, \Delta \sigma_{\text {accum }}\right)$ and an appropriate fading model. Further details of the model developed can be found in [11], [13].

The material model developed has been implemented in the ANSYS finite element program in order to analyse a special dissipative element known as the Buckling Restrained Brace (BRB). BRBs are composed of a slender steel core continuously supported by a concrete casing. The advantageous dissipative properties of the steel material are taken to the structural level by limiting the amplitude of buckling of the compressed bracing element, with a resulting significant energy dissipation. The performance of these elements depends on the contact/friction between the concrete and the Buckling Restraining Mechanism (BRM), which was the key issue in the current research work. Figure 9 presents the numerical model developed and the structural behaviour obtained under cyclic loading for two different core elements (CEW500 with $20 \times 25 \mathrm{~mm}$ and CEW800 with $20 \times 40 \mathrm{~mm}$ cross-sectional dimensions). The figure presents the observed buckling shape of the steel cores within the concrete casing, which is a complex sinusoidal shape with a relatively short buckling length. Restraints to eliminate longer buckling lengths give the energy-dissipation capacity of the structure. Using the numerical BRB model, the effect of the friction, air-gap size, and core shape could be analysed with respect to the energy dissipation capacity. A parametric study was also carried out, and improvements to the developed element, considering the appropriate air-gap and core parameters, are proposed [12].
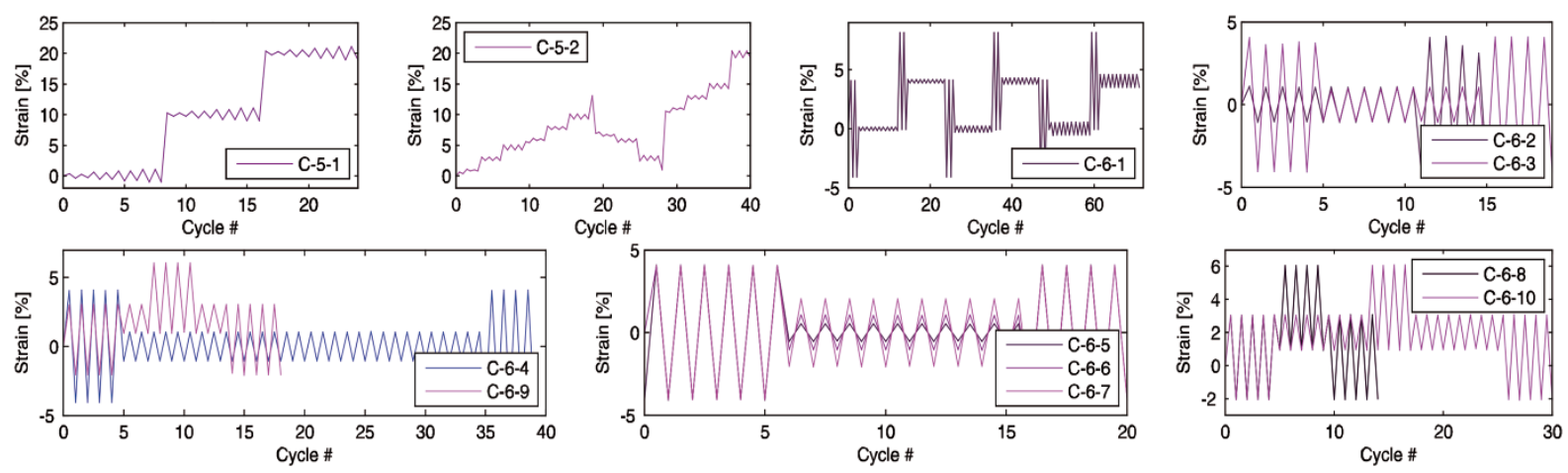

Fig. 8 Memory type or arbitrary protocols. Memory-Typ bzw. beliebige Belastungs-Protokolle. 


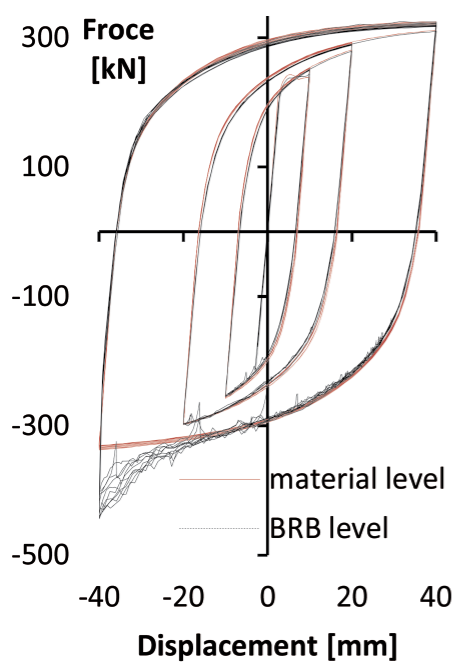

a)
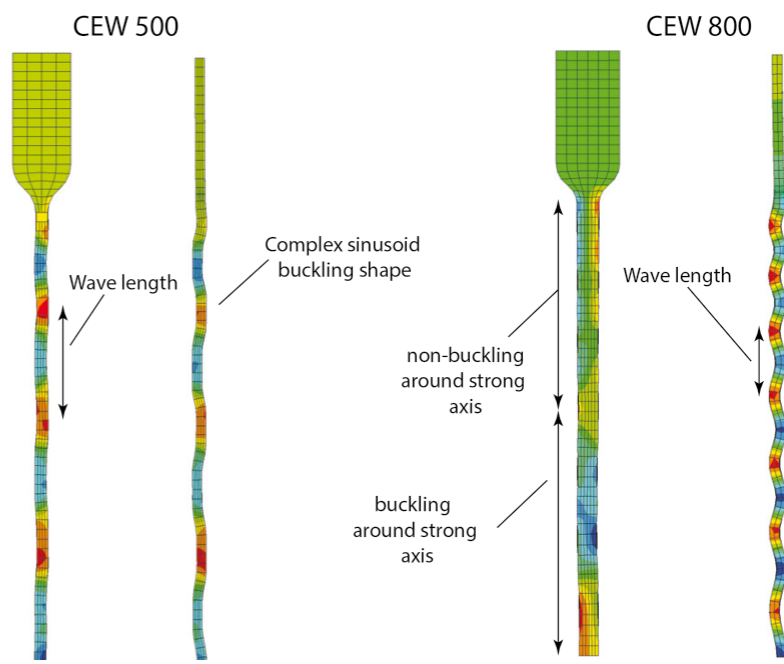

b)

Fig. 9 (a) Difference between the material and device level behaviour. (b) Distorted shape of core in the case of CEW500 and CEW800. (a) Unterschied zwischen dem Verhalten auf Material- und Bauteil-Ebene. (b) Verwindung des Stahlelementes bei CEW500 und CEW800.

The joint research activities on computational modelling overviewed in the previous parts of the paper resulted in a strong technical and personal background to the launching of a joint PhD education programme. The Department of Structural Engineering, BME, in cooperation with the Chair of Modelling and Simulation of Structures at the Bauhaus University, Weimar organized a PhD training course with the title of Computational Structural Design in 2017 and 2018. The PhD Course is organized as part of an Erasmus+ Strategic Partnership between 5 European Universities, as follows: BME, BUW Weimar, University of Ljubljana, University of Aveiro, J. J. Strossmayer University of Osijek. The relevant partners combine their resources and expertise to establish a network and a basis for the course. Besides the knowledge transfer, the participating PhD students have the opportunity to discuss their research topics with international experts from different disciplines and areas, to create their own networks, and to identify new ideas and topics for their future careers. The course introduces the advanced modelling techniques that are currently mainly used for research purposes with the aim of achieving their daily application in civil engineering practice.

The PhD students can learn how to use advanced modelling tools in the design of steel structures; what are their opportunities, limitations and special features. They are trained to know which modelling aspects are to be considered in the design, and which are the advantages of the advanced FEM-based design methods. In the course, several advanced design methods are presented, supported by computer simulations and on-site measurements or laboratory tests, as follows:

Numerical modelling techniques for advanced civil engineering problems;

- FEM-based design of bridges, and modelling of advanced bridge-erection and -monitoring methods;

- Application of measurement data or test results in the design of steel structures;

- Improvement methods for Eurocode-based design using numerical simulations and test results;

- Techniques for numerical modelling of manufacturing methods (welding simulation);

- Numerical modelling of special load effects such as atmospheric turbulence and fire.

The organization of the common $\mathrm{PhD}$ course extends and gives a special character to the cooperation of the two universities, which started from industrial needs, was followed by common $\mathrm{PhD}$ research works, and continues by turning the research results into the $\mathrm{PhD}$ education programme.

\section{Literature}

[1] M. Kachichian, L. Dunai L., R. Macdonald, F. Werner: Fullscale testing of cold-formed Z-purlins, Proceedings of International Colloquium on Stability and Ductility of Steel Structures; Professor Ottó Halász Memorial Session: SDSS2002, Budapest, Hungary, pp. 203-210, 2002.

[2] F. Werner: Design method for thin-walled, cold-formed load bearing elements - CFDM for the ASTRON light steel building system. Expert Report of the Institute of Construction, Bauhaus University, Weimar, Germany, 2008.
[3] M. Kachichian: Experimental analysis of cold-formed Z-purlin and sheeting interaction, PhD Dissertation, Budapest University of Technology and Economics, 2011.

[4] A.L. Joó, L. Dunai: Numerical studies on the ultimate behaviour of steel cold-formed purlins, Proceedings of the $6^{\text {th }}$ International Conference on Computational Structures Technology, Stirling, United Kingdom/Scotland, CivilComp Press, Paper 104, p.14, 2002. 


\section{Stab 4/2019}

\section{Aufsatz: 201900005}

[5] A.L. Joó: Analysis and design of thin-walled roof systems, PhD Dissertation, Budapest University of Technology and Economics, 2008

[6] M. Ch. Reuter: Multicriterial evaluation method for the prognosis quality of complex engineering models, $\mathrm{PhD}$ Dissertation, Bauhaus University, Weimar, Germany, 2011.

[7] N. Seres, L. Dunai, F. Werner: Numerical model development for the analysis of the composite action of a steel plate containing one single embossment and concrete, Proc. of the $8^{\text {th }}$ fib PhD Symposium in Civil Engineering, 20-23 June, Lyngby, Denmark, pp. 177-182, 2010.

[8] N. Seres, L. Dunai, F. Werner, M. Göbel: Investigation on the effect of 3D cold-forming. Experimental and numerical analyses of an embossment in thin-walled plate, Proc. of EUROSTEEL $2011-6^{\text {th }}$ European Conference on Steel and Composite Structures, August 31 - September 2, Budapest, Hungary, vol. A, pp. 147-152, 2011.

[9] N. Seres: Behaviour and resistance of concrete encased embossments in composite slabs, $\mathrm{PhD}$ Dissertation, Budapest University of Technology and Economics, 2012.

[10] V. Budaházy: Uniaxial cyclic steel behaviour and model for dissipative structures, PhD theses, Vásárhelyi Pál Doctoral School of Civil Engineering and Earth Sciences, Budapest University of Technology and Economics, 2015.
[11] V. Budaházy, L. Dunai: Parameter-refreshed Chaboche model for mild steel cyclic plasticity behaviour, Periodica Polytechnica, Civil Engineering, 57(2), 139, 2013.

[12] V. Budaházy, L. Dunai: Numerical analysis of concrete filled Buckling Restrained Braces. Journal of Constructional Steel Research, 115, 92-105, 2015.

[13] V. Budaházy: Cyclic plastic and buckling behaviour of steel material and structural elements, $\mathrm{PhD}$ Dissertation, Budapest University of Technology and Economics, 2015.

\section{Authors}

Prof. Dr.-Ing. László Duna

Dr. Balázs Kövesdi

Dr. Attila László Joó

Dr. Noémi Seres

Dr. Viktor Budaházy

Dr. Mansour Kachichian

Múegyetem rkp. 3

1111 Budapest, Hungary

Please complete addresses and mailing addresses 